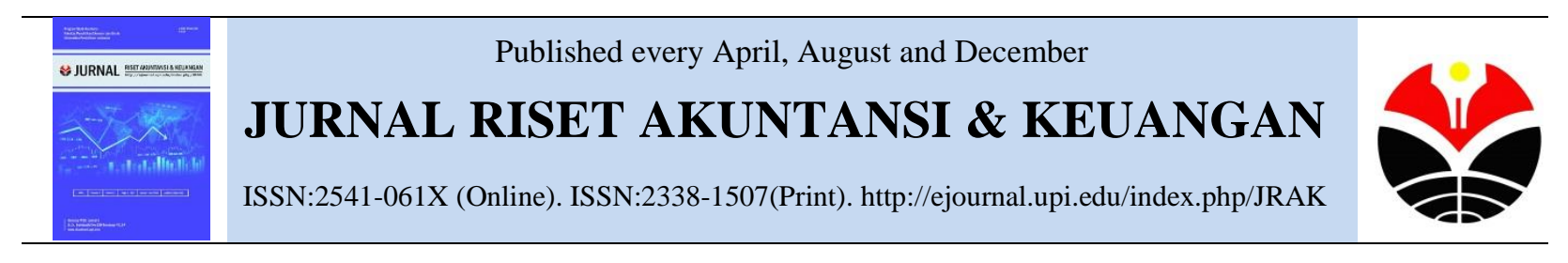

\title{
Pengaruh Sistem Pengendalian Mutu Kantor Akuntan Publik Terhadap Efektivitas Perencanaan Audit
}

\author{
Siti Nurrohmah ${ }^{1}$, Tb. Aman $\mathbf{F}^{2}$ \\ Program Studi Akuntansi, FPEB, Universitas Pendidikan Indonesia, Bandung, Indonesia
}

\begin{abstract}
This study aims to determine the description of Quality Control System of Public Accountant Firm and the Effectiveness of Audit Planner at Public Accounting Firm in Bandung and Cimahi, and to know the effect of public accountant quality control system on the effectiveness of audit planning. The research method used is descriptive-verification method with quantitative approach. Data obtained from primary data by using questionnaire. To analyze the data of the researcher using Spearman Rank correlation coefficient analysis and coefficient of determination. Based on the results of this study showed that the quality control system of public accounting firms in Bandung and Cimahi included in the category very well that is, equal to 91.63\%. While the effectiveness of audit planning included in category very good / effective that is equal to 85,56\%. Quality control system of public accountant office has a positive effect on the effectiveness of audit planning that is equal to 0,2079 or $20,79 \%$.

Keywords: Quality Control System of Public Accounting Firm; Effectiveness of Audit Planning.

Abstrak. Penelitian ini bertujuan untuk mengetahui gambaran Sistem Pengendalian Mutu Kantor Akuntan Publik dan Efektivitas Perencana Audit pada Kantor Akuntan Publik di Bandung dan Cimahi, serta untuk mengetahui pengaruh sistem pengendalian mutu kantor akuntan publik terhadap efektivitas perencanaan audit. Metode penelitian yang digunakan adalah metode deskriptif-verifikatif dengan pendekatan kuantitatif. Data diperoleh dari data primer dengan menggunakan kuesioner. Untuk menganalisis data peneliti menggunakan analisis koefisien korelasi Rank Spearman dan koefisien determinasi. Berdasarkan hasil penelitian ini menunjukan bahwa sistem pengendalian mutu kantor akuntan publik di Bandung dan Cimahi termasuk dalam kategori sangat baik yaitu, sebesar 91,63\%. Sedangkan efektivitas perencanaan audit termasuk dalam kategori sangat baik/efektif yaitu sebesar $85,56 \%$. Sistem pengendalian mutu kantor akuntan publik berpengaruh positif terhadap efektivitas perencanaan audit yaitu sebesar 0,2079 atau 20,79\%.

Kata Kunci: Sistem Pengendalian Mutu Kantor Akuntan Publik; Efektivitas Perencanaan Audit
\end{abstract}

Corresponding author. Email: ${ }^{2}$ aman.fathurochman@upi.edu

How to cite this article. Siti Nurrohmah, T. A. F. (2016). Pengaruh Sistem Pengendalian Mutu Kantor Akuntan Publik Terhadap Efektivitas Perencanaan Audit. Jurnal Riset Akuntansi Dan Keuangan Program Studi Akuntansi Fakultas Pendidikan Ekonomi Dan Bisnis Universitas Pendidikan Indonesia, 4(1), 957-966. Retrieved from http://ejournal.upi.edu/index.php/JRAK/article/view/7719

History of article. Received: January 2016, Revision: Maret 2016, Published: April 2016

Online ISSN: 2541-061X. Print ISSN: 2338-1507. DOI : 10.17509/jrak.v4i1.7719

Copyright@2016. Jurnal Riset Akuntansi dan Keuangan Program Studi Akuntansi FPEB UPI 


\section{PENDAHULUAN}

Saat ini di Indonesia mengalami perkembangan khususnya dalam bidang ekonomi dan bisnis, berdampak juga pada sektor dunia usaha. Perkembangan tersebut tentunya mengalami dampak terhadap peningkatan permintaan atas jasa audit. Berdasarkan peningkatan ini perusahaan akuntan publik harus dapat meningkatkan kinerja di segala aspek agar mampu bersaing, dimana banyaknya perusahaan besar dengan akuntan-akuntan berasal dari luar negeri yang masuk ke Indonesia.

Beberapa faktor yang mendukung tingginya permintaan jasa audit di Indonesia adalah karena pertumbuhan ukuran dan kompleksitas bisnis, perkembangan pasar modal, serta adanya perundang-undangan atau berbagai peraturan yang berlaku. Kondisi tersebut tentunya akan berpengaruh terhadap permintaan jasa audit di Kantor Akuntan Publik (KAP) dalam negeri, dimana lapangan kerja untuk para auditor dalam negeri semakin menurun. Selain itu, adanya auditor dalam negeri yang mengalami kegagalan saat melakukan audit menyebabkan integritas dan objektivitas profesi para akuntan publik menjadi menurun.

Beberapa kasus yang pernah terjadi terhadap kepercayaan akan auditor dan KAP menjadi sorotan publik di dalam maupun di luar negeri. Salah satunya yakni kasus yang dimuat oleh media online hukum 2 Mei 2001 mengenai pengakuan BPKP ada $10 \mathrm{KAP}$ yang melanggar SPAP. Dari BPKP mengakui bahwa hasil laporan Indonesia Corruption Watch (ICW) mengenai KAP yang melanggar ketentuan memang $70 \%$ sama dengan temuan BPKP. Persamaan itu, baik dari segi kebenaran maupun kelengkapan, setelah mengevaluasi $10 \mathrm{KAP}$ yang melakukan audit terhadap 35 Bank Beku Kegiatan Usaha (BBKU). ICW mengaku ada 10 KAP terindikasi kolusi, akan tetapi hasil penyelidikan mereka dianggap bersumber pada laporan BPKP yang telah masuk keranjang sampah alias tidak ditindaklanjuti. Pernyataan tersebut pihak BPKP membantah jika dikatakan KAP-KAP terindikasi kolusi ketika melakukan audit terhadap BBKU.
Dalam audit terhadap bank-bank tersebut, memang sebagian besar KAP memberikan penilaian wajar tanpa pengecualian kepada bank-bank yang sebulan kemudian ternyata collapse, sehingga terpaksa untuk dibekukan (www.hukumonline.com, 2001).

Beragam kondisi kasus pembekuan izin terhadap akuntan publik dan kantor akuntan publik juga terjadi di Indonesia, kasus ini kerap dilakukan oleh Departemen Keuangan. Hal ini didasarkan pada keputusan menteri keuangan republik Indonesia nomor 445/KM.1/2015 tanggal 29 Mei 2015 tentang sanksi pembekuan izin akuntan publik Ben Ardi, CPA penetapan sanksi pembekuan izin itu berdasarkan peraturan menteri keuangan No.17/PMK.01/2008 tentang Jasa akuntan publik. AP Ben Ardi, CPA, telah dikenakan sanksi pembekuan selama 6 bulan berdasarkan hasil pemeriksaan yang dilakukan oleh tim pemeriksaan dari PPPK terhadap akuntan Publik Ben Ardi, CPA dari KAP Jamaludin, Ardi, Sukinto dan Rekan. Dapat disimpulkan bahwa Akuntan Publik Ben Ardi, CPA belum sepenuhnya mematuhi standar audit (SA)-SPAP dalam pelaksanaan audit umum atas laporan keuangan PT. Bumi Citra Permai, Tbk Tahun Buku 2013. (www.pppk.kemenkeu.go.id, 2015)

Banyaknya kasus yang terjadi pada auditor seperti yang telah disebutkan, kemudian mendorong akuntan publik untuk membentuk suatu Ikatan Akuntan Indonesia (IAI) dimana harus memperhatikan dan mempersiapkan antisipasi terhadap hal-hal tersebut dengan sebaik-baiknya. terutama dalam melakukan perencanaan audit. Perencanaan audit yang dikerjakan secara efektif tentunya akan menghasilkan laporan audit yang lebih baik dan memadai, karena tahapan perencanaan audit menentukan dasar utama untuk menerima klien sampai dengan proses audit. Dalam perencaan audit juga harus memahami risiko-risiko bisnis klien serta hal-hal penting yang menyangkut dalam tahapan perencanaan audit agar terlaksana dengan efektif dan efisien. Beberapa upaya yang dilakukukan salah satunya adalah dengan melaksanakan sistem pengendalian mutu KAP yang dituangkan dalam Pernyataan 
Standar Pengendalian Mutu KAP (PSPM), pernyataan ini menetapkan bahwa setiap KAP wajib memiliki sistem pengendalian mutu dan menjelaskan unsur-unsur pengendalian mutu serta hal-hal yang terkait dengan implementasi secara efektif dalam sistem tersebut agar tidak terjadi kembali kesalahan maupun kasus korupsi yang pada auditor maupun KAP sendiri. Hal ini menjadi fokus Ikatan Akuntan Indonesia (IAI) dalam menjalankan sistem pengendalian mutu KAP dan tetap mengawasi izin akuntan publik dalam standar kerjanya.

Pengalaman kasus yang pernah terjadi serta dengan melihat kebijakan pemerintah terbaru dan didasari oleh adanya Sistem Pengendalian Mutu tersebut, hal ini tentunya akan berpengaruh langsung terhadap kualitas pelaksanaan penugasan audit dan proses penugasan dilapangan diantaranya terhadap perencanaan audit. Perencanaan keuangan audit merupakan tahap yang sangat penting dalam penugasan audit. Kualitas perencanaan audit yang baik, maka dengan sendirinya sangat menentukan kualitas tahap-tahap penugasan audit berikutnya. Dengan demikian, melalui penerapan sistem pengendalian mutu yang baik tentunya akan berpengaruh terhadap perencanaan audit. Karena di dalam system pengendalian mutu terdapat hal penting untuk melakukan awal perencanaan audit, yaitu menerima klien baru atau melanjutkan kembali dengan klien lama. Dengan demikian system pengendalian mutu yang diterapkan di KAP akan mempengaruhi terhadap proses perencanaan audit yang dilakukan secara efektif. Sehingga hal inilah yang menjadi faktor penulis untuk melakukan penelitian lebih dalam melalui judul “ pengaruh sistem pengendalian mutu Kantor Akuntan Publik terhadap efektivitas perencanaan audit dengan studi kasus pada KAP Bandung dan Cimahi. Adapun rumusan masalah untuk penelitian ini adalah sebagai berikut: (1) Bagaimana sistem pengendalian mutu pada KAP di Bandung dan Cimahi?; (2) Bagaimana efektivitas perencanaan audit pada KAP di Bandung dan Cimahi?; (3) Apakah sistem pengendalian mutu berpengaruh positif terhadap efektivitas perencanaan audit pada
KAP di Bandung dan Cimahi?. Dengan tujuan untuk mengetahui pengaruh dari sistem pengendalian mutu, efektivitas perencanaan audit, dan sistem pengendalian mutu terhadap efektivitas perencanaan audit pada KAP di Bandung .

\section{KAJIAN LITERATUR}

\section{Auditing}

Pengertian audit menurut The Committee on Basic Auditing Concept yang dikutip oleh Messier (2008, hlm. 7) dalam bukunya "Auditing and Assurance Service: A Systematic Approach" adalah:

"Auditing is a systematic process of objectively, obtaining, and evaluating evidence regarding assertions about economic action and event to ascertain the degree of correspondence between those assertions and establish criteria and communicating the result to interested users" Auditing adalah proses sistematis yang objektif untuk memperoleh dan mengevaluasi bukti-bukti yang menunjukkan tentang kegiatan ekonomi dan kegiatan untuk mengetahui dengan pasti tingkat koresponden antara tuntutan dan kriteria yang ditetapkan dan menyampaikan hasilnya kepada pihak yang berkepentingan.

Sehingga dapat dikatakan audit adalah pengumpulan bukti atas laporan keuangan perusahaan dengan informasi dan kriteria yang telah ditetapkan, serta pengumpulan dan evaluasi bukti yang dilakukan oleh auditor yang kompeten dan independen dan menghasilkan pelaporan audit yang menyatakan opini mengenai kewajaran atas laporan keuangan perusahaan. Auditor harus mampu mengumpulkan bukti audit, merencanakan dan menentukan prosedur audit, menguji serta mengevaluasi hasilnya, sehingga mampu memberikan keyakinan dan pendapat mengenai kewajaran atas laoran keuangan tersebut.

\section{Kantor Akuntan Publik}

Di dalam standar profesional akuntan publik 2011 menurut SK Menkeu No.43/KMK.017/1997 tertanggal 27 januari 1997 sebagaimana diubah dengan SK. 
Menkeu No.470/KMK.017/1999 tertanggal 4 Oktober 1999, Kantor Akuntan Publik (KAP) adalah lembaga yang memiliki izin dari Menteri Keuangan sebagai wadah bagi Akuntan Publik dalam menjalankan pekerjaannya.

Di dalam Undang-Undang Republik Indonesia Nomor 5 Tahun 2011 tentang Akuntan Publik Pasal 1 ayat 5 "Kantor Akuntan Publik, yang selanjutnya disingkat KAP, adalah badan usaha yang didirikan berdasarkan ketentuan peraturan perundangundangan dan mendapatkan izin usaha berdasarkan Undang-Undang." Otoritas Jasa Keuangan (OJK) merilis daftar KAP yang terdaftar di OJK per 30 September, tercatat 197 KAP dan AP sudah resmi sebagai auditor bank di OJK yang terbagi dalam golongan konvensional dan syariah. Perlu diketahui, AP Syariah memiliki sertifikat pendidikan dan pelatihan di bidang perbankan syariah. Sehingga, menurut ketentuan surat Bank Indonesia Nomor 7/57/DPbS 22 Desember 2005, dapat mengaudit bank yang melaksanakan kegiatan usaha berdasarkan prinsip syariah. (ojk.go.id).

Menurut Alvin A. Arens (2012, hlm. 19) Kantor Akuntan Publik bertanggung jawab mengaudit laporan keuangan historis yang dipublikasikan oleh semua perusahaan terbuka, kebanyakan perusahaan lain yang cukup besar, dan banyak perusahaan serta organisasi nonkomersial yang lebih kecil.

\section{Sistem Pengendalian Mutu}

Adapun sistem pengendalian mutu merupakan suatu prosedur yang diberlakukan oleh KAP untuk mendukung pekerjaan akuntan publik agar sesuai dengan standar pada setiap penugasannya. Sistem pengendalian mutu dapat memberikan penilaian yang tinggi terhadap KAP karena penerapan sistem pengendalian mutu dapat meningkatkan kepercayaan masyarakat terhadap pekerjaan suatu KAP. Dengan demikian sistem pengendalin mutu pada suatu organisasi auditor secara individu akan bervarisi dalam sifat dan lingkupnya. Hal ini karena terdapat beberapa faktor seperti ukuran dan tingkat otonomi kegiatan, sifat pekerjaan, struktur organsiasi, serta pertimbangan mengenai segi biaya dan manfaatnya.

Menurut Alvin A. Arens (2012, hlm. 38), unsur-unsur sistem pengendalian mutu, yaitu: 1) Leadership responsibilities for quality within the firm ("tone at the top"); 2) Relevant ethical requirements; 3) Acceptance and continuation of clients and engagements; 4) Human resources; 5) Engagement performance; 6) Monitoring.

\section{Efektivitas Perencanaan Audit}

Menurut Husein Umar (2003, hlm. 73) Efektivitas adalah kemampuan untuk memilih tujuan yang tepat. Manajer yang efektif memilih pekerjaan yang benar untuk dilaksanakan. Efektivitas berarti melakukan pekerjaan yang benar. Sedangkan menurut Ricky W. Griffin (2003, hlm. 88) efektivitas adalah melakukan hal-hal yang benar, dalam kaitannya dengan interaksi antara organisasi dan lingkungannya, efektivitas terutama berhubungan dengan seberapa baik suatu organisasi dapat memahami, bereaksi terhadap, dan mempengaruhi lingkungannya. Dari pengertian di atas disimpulkan bahwa, efektivitas merupakan kemampuan suatu organisasi untuk memperoleh dan memanfaatkan sumber daya yang ada sebaik mungkin dalam usahanya mencapai tujuan organisai, suatu unit dapat dikatakan efektif bila kontribusi keluaran yang dihasilkan semakin besar terhadap nilai pencapaian sasaran tersebut. Efektivitas juga dapat dikaitkan dengan tolak ukur keberhasilan suatu organisasi dalam mencapai tujuan organisasi tersebut yang berhubungan dengan hasil operasi perusahaan atau KAP. Standar audit yang berlaku umum mengenai pekerjaan lapangan yang pertama mengharuskan di lakukanya perencanaan yang memadai. Menurut Alvin A. Arens (2012, hlm. 200) Auditor harus melakukan perencanaan kerja yang memadai dan harus melakukan pengawasan secara seksama terhadap pekerjaan yang dilakukan oleh para assistenya.

Adapun tahapan perencanaan audit yaitu: Messier et.al (2008, hlm.145), 1) Penerimaan klien baru dan keberlanjuan klien yang sudah 
ada; 2) Membangun pemahaman mengenai perjanjian dengan klien; 3) Aktivitas pada perjanjian awal; 4) Menilai risiko bisnis klien dan membangun materialitas; 5) Merencanakan audit.

Selanjutnya setelah langkah 1 sampai 4 dilaksanakn, barulah auditor bisa merencanakan proses audit. Hal-hal yang diperhatikan dalam merencanakan audit adalah sebagai berikut: 1) Menilai kebutuhan spesialis; 2) Menilai kemungkinan adanya tindakan illegal; 3) Melakukan identifikasi pada pihak terkait; 4) Melakukan prosedur analisis awal; 5) Mempertimbangkan penambahan layanan nilai tambah.

\section{Hipotesis}

Hipotesis penelitian ini dirumuskan sebagai berikut: Sistem Pengendalian Mutu KAP berpengaruh positif terhadap Efektivitas Perencanaan Audit.

\section{METODOLOGI PENELITIAN}

\section{Metode Penelitian}

Desain penelitian yang digunakan dalam penelitian ini adalah desain kausal. Menurut Sugiyono (2011, hlm. 57) desain kausal adalah "penelitian yang bertujuan untuk menguji hubungan sebab akibat antara variabel independen (variabel yang mempengaruhi) dan variabel dependen (variabel yang dipengaruhi)". Maka dari itu peneliti ingin mengetahui mengenai pengaruh sistem pengendalian mutu terhadap efektivitas perencanaan audit di KAP yang tersebar di Bandung dan Cimahi.

\section{Populasi Penelitian}

Adapun populasi dari penelitian ini adalah semua Kantor Akuntan Publik yang berada di Bandung dan Cimahi. Berdasarkan data yang terdapat pada Direktor KAP IAPI terdaftar sebanyak 27 KAP yang ada di wilayah Bandung dan 3 KAP yang ada di wilayah Cimahi periode 2015.

\section{Sampel Penelitian}

Dalam menentukan sample penelitan, penulis menggunakan teknik nonprobability sampling yaitu teknik pengambilan sample yang tidak memberi peluang/kesempatan sama bagi setiap unsur atau anggota populasi untuk dipilih menjadi sample (Nazir, 2013, hlm 120). Penelitian ini menggunakan teknik convenience sampling. Menurut Sekaran (2009, hlm. 230) "Convenience sampling adalah desain pengambilan sample nonprobabilitas dimana sample penelitian diperoleh dari anggota populasi yang dapat dengan mudah diakses oleh peneliti". Dengan demikian, sample yang penulis ambil adalah 13 KAP di Bandung dan 2 KAP di Cimahi. Dalam hal ini, penulis mengambil 13 KAP di Bandung dan 2 di Cimahi sebagai sample karena KAP tersebut mudah diakses oleh peneliti dalam hal perizinan penelitian maupun dalam perizinan penyebaran kuisioner.

\section{Sumber Data}

Pada penelitian ini teknik pengumpulan data dilakukan dengan kuesioner. Data dikumpulkan melalui personal. Tujuan dari penyebaran kuesioner ini untuk mendapatkan data langsung yang berkaitan dengan masalah penelitian. Di dalam penelitian ini, kuesioner sendiri terbagi menjadi 2 (dua) bagian, yaitu kuesioner yang pertanyaannya berkaitan dengan sistem pengendalian mutu KAP sebagai variabel $X$, dan kuesioner yang pertanyaannya berkaitan dengan efektivitas perencanaan audit sebagai variabel Y. Kedua kuesioner tersebut akan disebarkan kepada auditor pada Kantor Akuntan Publik di Bandung dan Cimahi.

\section{Uji Validitas}

Pada penelitian ini uji validitas menggunakan korelasi Rank Spearman, dengan rumus sebagai berikut:

$r_{s}=1-\frac{6 \sum D_{i}^{2}}{n\left(n^{2}-1\right)}$

(Sudjana, 2004, hlm. 252)

Dalam penelitian ini, kuesioner yang dipakai berjumlah 48 item pertanyaan. Masing-masing 26 item pernyataan untuk variabel sistem pengendalian mutu kantor akuntan publik, dan 14 item pernyataan untuk variabel efektivitas perencanaan audit. Setelah melakukan penyebaran kuesioner, peneliti kemudian melakukan pengolahan data awal seperti uji validitas dengan menggunakan software IBM SPSS Statistics 20. Berikut ini adalah gambaran hasil validitas kuesioner 
variabel sistem pengendalian mutu kantor akuntan publik.

Berikut adalah gambaran hasil validitas kuesioner variabel efektivitas perencanaan audit. Berdasarkan tabel pengujian yang disajikan 12 item pertanyaan pada variabel efektivitas perencanaan audit dinyatakan valid, sedangkan 2 item pertanyaan tidak valid sehingga tidak dapat diikutsertakan dalam pengujian selanjutnya, yakni uji reliabilitas.

\section{Uji Reliabilitas}

Tabel Hasil Pengujian Reliabilitas

\begin{tabular}{llll} 
Variabel & $\begin{array}{l}\text { Reliabilitas } \\
\text { Hasil } \\
\text { Perhitungan }\end{array}$ & Batasan & Keterangan \\
\hline Sistem Pengendalian Mutu KAP & 0,938 & 0,60 & Reliabel \\
Efektivitas Perencanaan Audit & 0,687 & 0,60 & Reliabel \\
\hline
\end{tabular}

\section{Sumber: data diolah}

Dengan demikian diketahui bahwa kuesioner dalam variabel sistem pengendalian mutu kantor akuntan publik dan efektivitas perencanaan audit adalah reliabel.

\section{Analisis Data atas Tanggapan Responden}

Instrumen dalam penelitian ini berupa kuesioner dengan pengukuran skala likert. Dimana data yang diperoleh dari hasil pengisian kuesioner selanjutnya akan dianalisis dengan menghitung masing-masing skor dari setiap pertanyaan sehingga didapat kesimpulan mengenai kondisi setiap item pertanyaan pada obyek yang diteliti.

\section{Analisis Koefisien Korelasi}

Untuk menguji hipotesis digunakan analisis korelasi. Dengan kata lain, koefisien korelasi ini digunakan untuk menunjukkan sejauh mana hubungan yang terjadi diantara variabel bebas dan variabel terikat.

Hipotesis yang diajukan diuji dengan menggunakan analisis korelasi Rank Spearman karena data berskala ordinal. Menurut Sarwono dan Suhayati, (2010, hlm. 80) Korelasi Spearman digunakan untuk mengetahui hubungan atau pengaruh antara dua variabel berskala ordinal, yaitu variabel bebas dan variabel tergantung. Adapun rumus
Uji reliabilitas dilakukan setelah alat ukur dinyatakan valid. Pengujian reliabilitas pada penelitian ini menggunakan teknik dari Cronbach Alpha. Cronbach Alpha merupakan salah satu koefisien relibilitas yang paling sering digunakan. Berikut rumus yang digunakan: Suharsimi Arikunto (2010, hlm. 239)

$$
r_{11}=\left(\frac{k}{k-1}\right)\left(\frac{1-\sum \sigma_{b}{ }^{2}}{\sigma_{t}{ }^{2}}\right)
$$

Berikut hasil dari pengujian reliabilitas: dari korelasi Rank Spearman adalah sebagai berikut:

$$
r_{s}=1-\frac{6 \sum D_{i}^{2}}{n\left(n^{2}-1\right)}
$$

Setelah nilai koefisien determinasi diperoleh, maka akan didapatkan hipotesis sebagai berikut:

Ho : $r_{s}<0$, Sistem Pengendalian Mutu KAP tidak berpengaruh positif terhadap Efektivitas Perencanaan Audit pada Kantor Akuntan Publik di Bandung dan Cimahi

Ha $: r_{s} \geq 0$, Sistem Pengendalian Mutu KAP berpengaruh positif terhadap Efektivitas Perencanaan Audit pada Kantor Akuntan Publik di Bandung dan Cimahi

\section{Analisis Koefisien Determinasi}

Menurut Sugiyono (2012, hlm. 216), koefisien determinasi adalah koefisien penentu, karena varian yang terjadi pada variabel dependen dapat dijelaskan melalui variabel yang terjadi pada variabel independen. Analisis ini digunakan untuk menilai seberapa besar variabel $\mathrm{X}$ dapat memberikan pengaruh terhadap Variabel $\mathrm{Y}$ dengan rumus sebagai berikut: (Sugiyono, 2012, hlm. 217). 


$$
K d=r_{s}^{2} \times 100 \%
$$

\section{HASIL DAN PEMBAHASAN}

Setelah menganalisis dan menguji hipotesis, maka berikut ini adalah penjelasan penulis atas hasil analisis data dan pengujian hipotesis yang telah dilakukan sebelumnya. Berdasarkan perhitungan statistika dengan bantuan software SPSS 20 for windows yaitu dengan menggunakan teknik korelasi rank speraman untuk menguji hipotesis tersebut.

\section{Gambaran Sistem Pengendalian Mutu} Kantor Akuntan Publik

Data yang diperoleh dalam penelitian ini bersumber dari kuesioner yang dibagikan pada 15 orang responden, yaitu auditor pada Kantor Akuntan Publik di Bandung dan Cimahi. Setelah peneliti melakukan perhitungan dengan menggunakan bantuan software SPSS 20 for windows, jawaban responden atas pernyataan-pernyataan yang ditujukan dalam sistem pengendalian mutu KAP menghasilkan angka 91,63\%. Berdasarkan tabel interpretasi skor (tabel 3.6) termasuk kedalam kategori sangat baik/efektif karena mayoritas responden menjawab pada rentang positif tertinggi. Tingkat interpretasi skor tertinggi adalah sebesar 93,55\% terdapat pada dimensi Sumber Daya Manusia. Sedangkan tingkat interpretasi terendah adalah sebesar $87,33 \%$ terdapat pada dimensi Pemantauan, yaitu pada indikator melakukan inspeksi periodik terhadap sejumlah perikatan yang telah selesai dirancang yaitu sebesar $84 \%$ dengan kategori sangat baik. Hal tersebut menunjukan bahwa sistem pengendalian mutu KAP rata-rata sudah berjalan secara sangat efektif dan sangat baik pada Kantor Akuntan Publik di Bandung dan Cimahi.

\section{Gambaran Efektivitas Perencanaan Audit}

Data yang diperoleh dalam penelitian ini bersumber dari kuesioner yang dibagikan pada 15 orang responden, yaitu auditor pada Kantor Akuntan Publik di Bandung dan Cimahi. Setelah peneliti melakukan perhitungan dengan menggunakan bantuan software SPSS 20 for windows, jawaban responden atas pernyataan-pernyataan yang ditujukan dalam efektivitas perencanaan audit KAP menghasilkan angka $85,56 \%$. Berdasarkan tabel interpretasi skor (tabel 3.6) termasuk kedalam kategori sangat baik/efektif karena mayoritas responden menjawab pada rentang positif tinggi. Tingkat interpretasi skor tertinggi adalah sebesar $92,67 \%$ yaitu, pada dimensi aktivitas pada perjanjian awal. Sedangkan tingkat interpretasi skor dua terendah adalah sebesar $77,33 \%$ yaitu, pada dimensi penerimaan klien baru dan berkelanjutan klien yang sudah ada dan $81,33 \%$ yaitu, pada dimensi menilai risiko bisnis klien dan membangun materialitas, kedua dimensi tersebut dalam kategori baik/efektif. Dengan rata-rata tersebut menunjukan bahwa efektivitas perencanaan audit pada Kantor Akuntan Publik di Bandung dan Cimahi sangat efektif dan baik.

\section{Pengaruh Sistem Pengendalian Mutu Kantor Akuntan Publik Terhadap Efektivitas Perencanaan Audit}

Untuk mengetahui adanya pengaruh antara variabel tersebut, peneliti menggunakan korelasi Rank Spearman terlebih dahulu untuk mengetahui keterdapatan hubungan antar variabel, kemudian dilanjutkan dengan pengujian koefisien determinasi untuk mengukur besar pengaruhnya. Dari hasil perhitungan tersebut dapat disimpulkan bahwa sistem pengendalian mutu KAP berpengaruh positif terhadap efektivitas perencanaan audit. Hal ini berdasarkan hasil perhitungan korelasi Rank Spearman menggunakan bantuan software IBM SPSS Statistics 20 pada tabel 4.19, diketahui koefisien korelasi untuk hipotesis ini adalah 0,456. Dengan demikian perhitungan koefisien korelasi yang dihasilkan lebih besar dari $0(0,456>0)$. Hasil tersebut mengindikasikan bahwa terdapat hubungan positif di antara kedua variabel.

Sedangkan besarnya persentase pengaruh variabel sistem pengendalian mutu KAP terhadap efektivitas perencanaan audit dapat dilihat dari koefisien determinasi, yaitu sebesar 0,2079 atau $20,79 \%$. Sehingga dapat disimpulkan sistem pengendalian mutu KAP berpengaruh positif 
terhadap efektivitas perencanaan audit sebesar $20,79 \%$.

\section{SIMPULAN}

Berdasarkan hasil penelitian yang dilakukan terhadap 15 auditor yang bekerja di KAP Bandung dan Cimahi dan hasil pembahasan mengenai sistem pengendalian mutu KAP terhadap efektivitas perencanaan audit pada bab sebelumnya, maka dapat ditarik kesimpulan sebagai berikut:

Sistem Pengendalian Mutu Kantor Akuntan Publik di Bandung dan Cimahi termasuk dalam kategori sangat baik yaitu, sebesar 91,63\%. Hal ini menunjukkan bahwa KAP telah menerapkan Sistem Pengendalian Mutu KAP dengan sangat baik dan efektif. Tingkat interpretasi terendah adalah sebesar $87,33 \%$ terdapat pada dimensi Pemantauan, yaitu pada indicator melakukan inspeksi periodik terhadap sejumlah perikatan yang telah selesai dirancang yaitu sebesar $84 \%$ dengan kategori sangat baik. Hal tersebut menunjukkan bahwa system pengendalian mutu KAP rata-rata sudah berjalan secara sangat efektif dan sangat baik pada Kantor Akuntan Publik di Bandung dan Cimahi.

Efektivitas Perencanaan Audit pada Kantor Akuntan Publik di Bandung dan Cimahi termasuk dalam kategori sangat baik/efektif, yaitu sebesar $85,56 \%$. Hal ini menunjukkan bahwa auditor telah menjalankan setiap penugasan dengan sangat baik dan efektif, sebelum melaksanakan pemeriksaan Kantor Akuntan Publik tersebut terlebih dahulu merencanakan pemeriksaan yang akan dilakukan dengan baik.

Sistem pengendalian mutu KAP berpengaruh positif terhadap efektivitas perencanaan audit sebesar $20,79 \%$. Hal ini membuktikan bahwa jika sistem pengendalian mutu diterapkan dengan baik maka perencanaan audit akan lebih efektif. Walaupun memiliki hubungan positif, derajat hubungan antara kedua variable tersebut masih ada hal-hal lain di samping sistem pengendalian mutu KAP yang dapat meningkatkan efektivitas perencanaan audit.

Berdasarkan hasil penelitian yang telah diuraikan dan simpulan yang diperoleh, maka terdapat beberapa saran yang penulis sampaikan sehubungan dengan pengaruh sistem pengendalian mutu kantor akuntan publik terhadap efektivitas perencanaan audit beserta hal lainnya yang terkait, yaitu:

Bagi Kantor Akuntan Publik

Efektivitas perencanaan audit perlu ditingkatkan pada dimensi penerimaan klien baru dan berkelanjutan klien yang sudah ada masih berkategori baik dengan tingakt interpretasi skor yang sangat rendah. Kantor Akuntan Publik harus mampu meningkatkan perencanaan audit dalam penerimaan klien baru dan melanjutkan klien yang sudah ada, agar perencanaan audit berjalan efektif sesuai dengan sistem pengendalian mutu yang diterapkan oleh KAP.

Bagi peneliti selanjutnya:

Peneliti menyarankan agar menambah sampel penelitian, karena dalam penelitian ini peneliti menggunakan $15 \mathrm{KAP}$, sehingga tidak dapat digeneralisir sebagai gambaran keseluruhan yang terjadi di KAP Bandung dan Cimahi.

Bagi peneliti selanjutnya diharapkan dapat mengembangkan penelitian ini dengan menggunakan variabel variabel lain yang diyakini berpengaruh terhadap efektivitas perencanaan audit yang tidak dibahas dalam penelitian ini.

\section{DAFTAR PUSTAKA}

A. Iqbal. (2008). Pengaruh Sistem Pengendalian Mutu Kantor Akuntan Publik Non-Afilasi di Jakarta. Jurnal Akuntansi Dan Keuangan, 7(2), 186195.

Agoes, Sukrisno. (2004). Auditing (Pemeriksaan Akuntan) oleh Kantor Akuntan Publik. Edisi Ketiga. Penerbit Fakultas Ekonomi Universitas Trisakti . (2012). Auditing: Petunjuk Praktis Pemeriksaan Akuntan oleh Akuntan Publik. Jakarta: Salemba Empat.

Anggraeni dan Badera (2013). Pengaruh Penerapan Sistem Pengendalian Mutu Pada Kinerja Auditor di Kantor 
Akuntan Publik di Provinsi Bali. EJurnal Akuntansi Universitas Udayana. 5(2), 307-325

Arens, Alvin A. (2012). Jasa Audit dan Assurance. Jakarta: Salemba Empat

Arens et. al. (2012). Auditing and Assurance Services An Integrated approach New Jersey: Pearson Education, Inc

Surhayati, Ely dan Kurnia R, Siti (2009). Auditing (Konsep Dasar dan Pedoman Pemeriksaan Akuntan Publik). Graha Ilmu: Yogyakarta

Griffin, Ricky W. (2003). Manajemen, Edisi Ketujuh. Jakarta: Erlangga

IAPI. (2013). Standar Audit (SA 220)/Institut Akuntan Publik ikaIndonesia. Jakarta: Salemba Empat

Ikatan Akuntan Indonesia. (2000). Standar Profesi Akunta Publik. Bagian Penerbitan STIE YKPN.

Messier, et. al. (2008). Auditing and Assurance Service. Sixth Edition. New York: McGraw Hill

Nazir. (2013). Metodologi penelitian. Bogor: Ghalia Indonesia.

Sekaran, Uma. (2009). Metodelogi Penelitian Untuk Bisnis. Jakarta: Salemba Empat

Suharsimi Arikunto (2010). Prosedur Penelitian (Suatu Pendekatan Praktik). Jakarta: RINEKA CIPTA.

Sugiyono. (2010). Metode Penelitian Bisnis. Bandung: Alfabeta.

Sugiyono. (2011). Metode Penelitian Bisnis (Pendekatan Kualitatif, Kuantitatif, dan $R \& D)$. Bandung: Alfabeta.

. (2012). Metode Penelitian Bisnis. Bandung. Alfabeta.

Sugiyono. (2012). Metode Penelitian Bisnis Pendekatan Kuantitatif, Kualitatif dan $R \& D$. Bandung: Alfabeta

Umar, Husein. (2003). Business An Introduction. Jakarta: Gramedia

Undang-Undang Republik Indonesia No. 5 Tahun 2011 Tentang Akuntan Publik

(2013). Sejarah IAPI. [Online]. Tersedia: http://www.iapi.or.id/iapi/sejarah_iapi. php. [29 April 2014]

(2014). Daftar KAP/Akuntan Publik Terdaftar Sebagai Auditor Bank di OJK.
[Online]. Tersedia: www.ojk.go.id. [28 April 2015]

BPKP Akui 10 KAP Melanggar SPAP. [Online]. Tersedia: www.hukumonline.com/berita/baca/ho 12554/bpkp-akui-10-kantor-akuntanpublik-melanggar-spap

Skandal Penyuapan Pajak Kantor Akuntan KPMG Indonesia digugat di AS. [Online]. Tersedia:

Sanksi Pembekuan Ben Ardi. [Online]. Tersedia:

http://pppk.kemenkeu.go.id/Sanksi/Ge tPdfFile?fileName=Juni $\% 20$ -

$\% 20$ sanksi\%20pembekuan $\% 20$ ben $\% 2$ 0ardi.pdf 


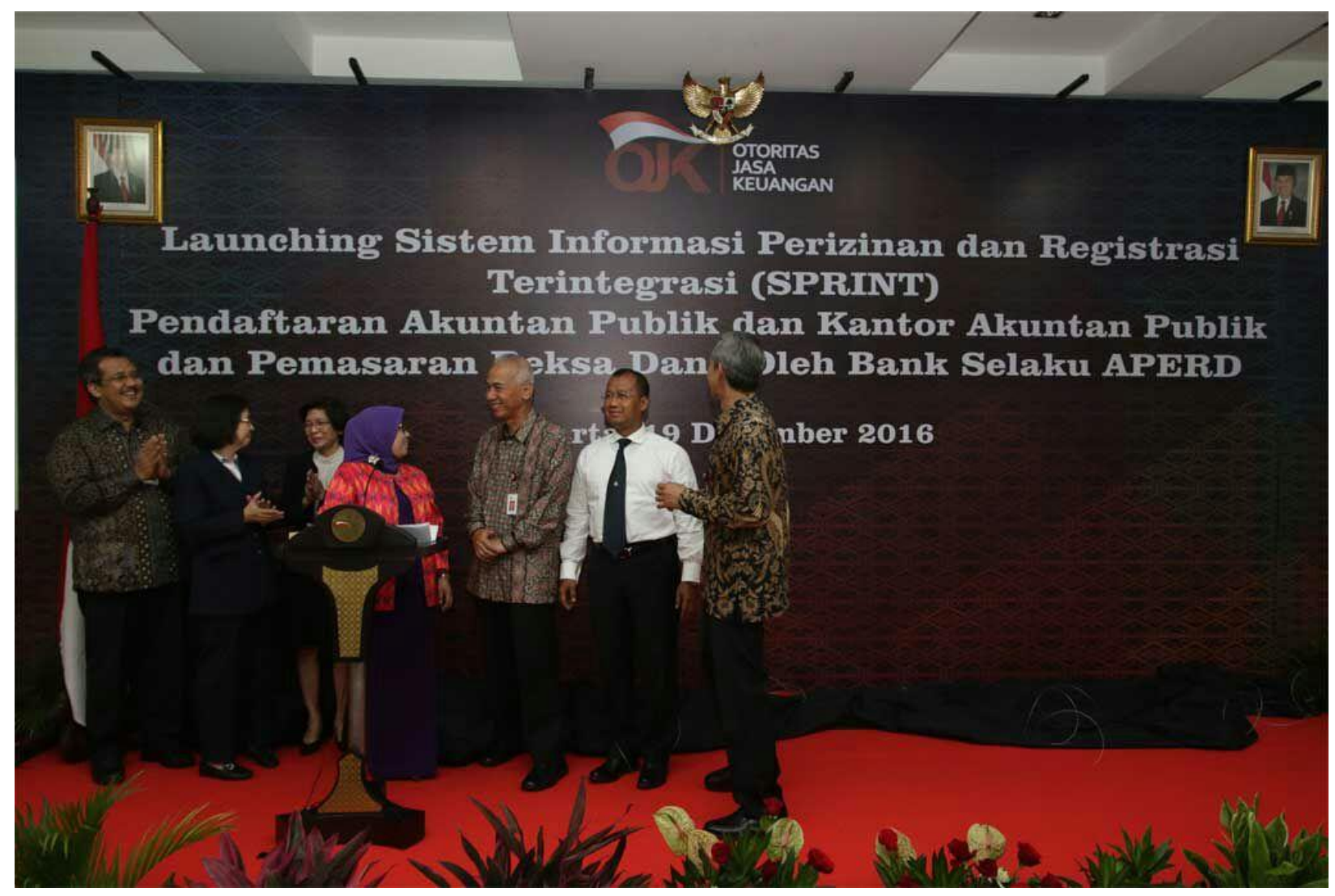

Sumber http://agolf.xyz/wp-content/uploads/2016/12/IMG-20161219-WA0000.jpg

Program OJK dalam meluncurkan Sistem Informasi Perizinan dan Registrasi Terintegrasi (SPRINT) Penjualan Reksa Dana Melalui Bank Selaku APERD (Agen Penjual Efek Reksa Dana) dan Pendaftaran Akuntan Publik sebagai upaya mempercepat dan menyederhanakan proses perijinan. Sistem ini mampu mengintegrasikan seluruh proses perizinan serta registrasi dari berbagai kompartemen di OJK yaitu pengawas pasar modal, perbankan dan industri keuangan non bank. Sistem yang dikembangkan adalah Melalui SPRINT, proses perijinan penjualan reksa dana melalui bank selaku APERD dipersingkat dari 105 hari menjadi 19 hari kerja saja. Sementara proses pendaftaran Akuntan Publik yang sebelumnya diajukan ke masingmasing kompartemen di OJK dengan waktu pemrosesan yang berbeda-beda, namun dengan SPRINT bisa diselesaikan dalam waktu 20 hari kerja. 